\title{
PENGUATAN KARAKTER RELIGIUS SISWA MELALUI PEMBELAJARAN SAINS BERNUANSA PENDIDIKAN NILAI
}

\author{
Yoyo Zakaria Ansori \\ 1,2,3 Universitas Majalengka, Jl. K.H. Abdul Halim No. 103 Majalengka, Jawa Barat \\ e-mail: al.anshory0928@unma.ac.id
}

\begin{abstract}
ABSTRAK
Pendidikan yang berorientasi pembangunan karakter religius sangat diperlukan dalam rangka mengembangkan dan menguatkan sifat mulia kemanusiaan ditengah kekhawatiran terhadap fenomena sosial yang muncul akhir-akhir ini yang sudah sangat meresahkan. Seperti fenomena kekerasan dalam menyelesaikan masalah, meningkatnya perilaku merusak diri, lunturnya budaya toleransi, menurunnya perilaku berbahasa santun, perilaku kejujuran, dan menurunnya rasa keagamaan dikalangan siswa. Tujuan dari penelitian ini adalah untuk membangkitkan kesadaran siswa akan keberadaan Tuhan di alam sebagai maha pencipta dan sifat-sifat Tuhan lainnya untuk selanjutnya mampu merawat dan menjalankan perintahnya. Kondisi tersebut dapat tercapai melalui pembelajaran yang terintegrasi dengan mengaitkan sains dengan agama. Metode yang digunakan dalam penelitian ini adalah metode deskriptif yaitu usaha peneliti untuk memecahkan masalah aktual (up to date) dengan jalan mengumpulkan data, menyusun atau mengklasifikasinya, menganalisis, dan menginterpretasikannya. Adapun teknik pengumpulan data dengan menggunakan studi pustaka (library research) dimana peneliti mengumpulkan data dengan cara membaca, mempelajari, dan menganalisis jurnal-jurnal, buku, artikel dari peneliti terdahulu. Dari penelitian ini diharapkan lahirnya pemahaman bahwa membangun karakter religius dapat terwujud melalui pembelajaran sains berbasis pendidikan nilai.
\end{abstract}

Kata Kunci :Karakter religius, sains, pendidikan nilai.

\section{ABSTRACT}

Education which is oriented towards building religious character is very much needed in order to develop and strengthen the noble nature of humanity amid the concerns over social phenomena that have arisen lately which have been very troubling. Such as the phenomenon of violence in solving problems, increasing self-destructive behavior, fading culture of tolerance, declining polite language behavior, honesty behavior, and decreasing religious sense among students. The purpose of this research is to raise students' awareness of the existence of God in nature as a creator and other attributes of God to further be able to care for and carry out their commands. This condition can be achieved through integrated learning by linking science with religion. The method used in this research is descriptive method that is the researchers' effort to solve the actual problem (up to date) by collecting data, compiling or classifying it, analyzing, and interpreting it. The data collection technique is using library research where researchers collect data by reading, studying and analyzing journals, books and articles from previous researchers. From this research, it is hoped that the emergence of an understanding that building religious character can be realized through learning science based on values education.

Keywords: Religious character, science, value education. 


\section{PENDAHULUAN}

Pendidikan yang baik dan bermutu merupakan harapan dan tujuan bagi bangsa Indonesia, pendidikan diharapkan dapat melahirkan manusia Indonesia seutuhnya, demikian yang diamanatkan oleh aturan normatif kita (Ansori, 2019). Di sekolahlah pendidik diharapkan mampu menginternalisasikan nilai dan siswa belajar untuk mengaktualisasikan nilai-nilai yang diterima secara langsung maupun tidak langsung. Aktualisasi nilai inilah yang menjadi acuan keberhasilan pembinaan karakter siswa di sekolah, karena karakter hanya bisa dilihat dari perilaku, bukan dari pemahaman teoritis. Dengan kata lain, iklim sekolah mempengaruhi tata cara bagaimana siswa mengerjakan segala hal di sekolah (Stronge, 2013 hlm. 18). Senada dengan pendapat tersebut menurut Ansori (2017) the character does not only build and develop in every individual, but also in educational institutions.

Pendidikan yang berorientasi pembangunan karakter religius sangat diperlukan dalam rangka mengembangkan dan menguatkan sifat mulia kemanusiaan agar manusia sebagai makhluk tertinggi dimuka bumi ini tidak terpeleset jatuh menjadi makhluk yang tidak manusiawi (Nurihsan 2016, hal. 60). Beberapa pendapat disampaikan oleh beberapa ahli akan pentingnya pendidikan karakter sebagaimana menurut Covey (El-Bassiouny, 2008) "As dangerous as a little knowledge is, even more dangerous is much knowledge without a strong principled character.... Yet all too often in the academic world, that's exactly what we do by notfocusing on the character development of young people". Roosevelt "to educate a person in mind and not in morals is to educate a menace society".
King Jr. (intelligence plus character - that is the goal of true education).

Beberapa pendapat di atas menjelaskan akan bahayanya sedikit ilmu pengetahuan bagi manusia, namun lebih berbahaya lagi banyak pengetahuan tapi tidak berkarakter, tidak adanya karakter akan menyebabkan hilangnya generasi penerus suatu bangsa. Disamping itu menjelaskan bahwa mendidik seseorang dalam aspek kecerdasan otak tanpa aspek moral melahirkan ancaman bagi masyarakat sehingga kecerdasan yang berkarakter adalah tujuan akhir pendidikan

Kehilangan karakter religius berdampak hilangnya kendali mengakibatkan mudahnya siswa tergelincir dalam perilaku yang tidak baik. Kekhawatiran itu nampak pada fenomena sosial saat ini yang sudah sangat meresahkan, fenomena kekerasan dalam menyelesaikan masalah, meningkatnya perilaku merusak diri, seperti narkoba, alkohol dan seks bebas, menurunnya perilaku sopan santun, menurunnya perilaku kejujuran, menurunnya rasa kebersamaan, dan menurunnya rasa gotong royong di antara anggota masyarakat (Daniah, 2016).

Sementara menurut Sauri (2009) bahwa persoalan utama yang dihadapi oleh dunia pendidikan dewasa ini adalah menurunnya moralitas peserta didik sebagai dampak langsung dari pergeseran nilai yang memudarkan budaya malu masyarakat. Sedangkan menurut Hakam (2015) hadirnya perundang-undangan dan mata pelajaran nilai moral, seharusnya berpengaruh terhadap kebermoralan masyarakat terutama peserta didik. Namun, dalam kehidupan sehari-hari terdapat ketimpangan sosial yang mengindikasikan ketidakbermoralan. Pelanggaran moral di lingkungan sekolah terangkum seperti di bawah ini:

Tabel 1. Kasus Kekerasan di Sekolah Dasar

\begin{tabular}{clc}
\hline No & \multicolumn{1}{c}{ Kasus } & Prosentase \\
\hline 1 & Siswa pernah mengalami kekerasan di sekolah & $84 \%$ \\
2 & Siswa mengalami kekerasan di sekolah & $75 \%$ \\
3 & Siswa laki-laki menyebutkan bahwa guru atau petugas sekolah & $45 \%$ \\
& merupakan pelaku kekerasan & \\
\hline
\end{tabular}




\begin{tabular}{clc}
\hline 4 & $\begin{array}{l}\text { Siswa perempuan menyebutkan bahwa guru atau petugas } \\
\text { sekolah merupakan pelaku kekerasan }\end{array}$ & $22 \%$ \\
5 & $\begin{array}{l}\text { Siswa melaporkan pernah mengalami kekerasan fisik teman } \\
\text { sebaya }\end{array}$ & $40 \%$ \\
6 & $\begin{array}{l}\text { Siswa melaporkan mengalami perundungan (bullying) di } \\
\text { sekolah. }\end{array}$ & $50 \%$ \\
\hline
\end{tabular}

Semua fenomena tersebut mengindikasikan bahwa belum berhasilnya pendidikan moral dan pendidikan karakter secara memuaskan di sekolah. Karakter religius merupakan salah satu pilar utama dalam suatu kurikulum. Melalui pembentukan karakter religius diharapkan akan menjadi pondasi yang kuat dalam penguatan karakter anak agar dapat menjadi bekal bagi dirinya kelak di kemudian hari. Sikap religius merupakan sikap dan perilaku yang dekat dengan hal-hal spiritual. Seseorang disebut religius ketika ia merasa perlu dan berusaha mendekatkan dirinya dengan Tuhan Yang Maha Esa, dan patuh melaksanakan ajaran agama yang dianutnya.

Nilai religius berorientasi kepada nilai keimanan sebagai dasar pemikiran dan tindakan yang berhubungan dengan kesadaran akan kekuasaan Tuhan Yang Maha Esa dengan sifat asma ulhusna lainnya. Nilai keimanan ini dapat meningkatkan ketakwaaan kepada Tuhan Yang Maha Esa. Menurut pandangan Einstein (Yudianto, 2015) bahwa nilai religius sains adalah nilai yang dapat membangkitkan kesadaran akan keberadaan Tuhan di alam sebagai maha pencipta dan sifat-sifat Tuhan lainnya. Kesadaran manusia terhadap kekuasaan Tuhan tersebut akan muncul bila dihadapkan kepada segala keteraturan fenomena alam, keseimbangan alam, peristiwa sebab akibat yang terjadi di alam, daur hidup materi dan aliran energi, dan berbagai keunikan dan keanekaragaman di alam yang mempesona, baik ditingkat mikrokospik maupun makrokosmik. Pada tingkat mikrokosmik, seperti berbagai stuktur jaringan tumbuhan maupun hewan memiliki keunikan keanekaragaman tersendiri, karena manusia tidak mungkin dapat melakukan hal yang sama. Demikian pula pada tingkat makrokosmik, manusia dapat mempelajari hukum kosmik itu sendiri seperti digerakan oleh sebuah mesin yang maha besar, begitu teraturnya peredaran bintang-bintang, planet-planet, satelit-satelit, dan benda-benda luar angkasa lainnya.

Fenomena tersebut untuk dapat mengambil hikmah atau pelajaran dari berbagai fenomena alam yang ditunjukan oleh Allah swt, manusia mesti mempelajari dan mengikuti sesuai dengan hukum alam yang berlaku. Artinya aturan main dalam kehidupan manusia yang aman dan tertib harus sesuai dengan petunjuk ayat-ayat Allah, baik ayat qauliyah maupun kauniyah.Dengan cara itu maka kesadaran akan keberadaan Tuhan di alam sebagai maha pencipta dan sifat-sifat Tuhan lainnya dapat dibangkitkan sehingga dapat melahirkan perilaku religius melalui usaha mendekatkan dirinya dengan Tuhan Yang Maha Esa, dan patuh melaksanakan ajaran agama yang dianutnya.

\section{METODE}

Metode yang digunakan dalam penelitian ini adalah metode penelitian deskriptif. Kutha (2010) metode deskriptif adalah analisis yang dilakukan dengan cara mendeskripsikan fakta-fakta yang kemudian disusul dengan analisis, tidak semata-mata menguraikan, melainkan juga memberikan pemahaman dan penjelasan secukupnya. Adapun teknik pengumpulan data dalam penelitian ini dengan menggunakan studi pustaka (library research) dimana peneliti mengumpulkan data dengan cara membaca, mempelajari, dan menganalisis jurnal-jurnal, buku, artikel dari peneliti terdahulu yang ada hubungannya dengan obyek penelitian.

Studi Kepustakaan Menurut Sugiyono (2016), berkaitan dengan kajian teoritis dan referensi lain yang berkaitan dengan nilai, 
budaya dan norma yang berkembang pada situasi sosial yang diteliti, selain itu studi kepustakaan sangat penting dalam melakukan penelitian, hal ini dikarenakan penelitian tidak akan lepas dari literaturliteratur ilmiah. Data diperoleh dari data yang relevan terhadap permasalahan yang akan diteliti dengan melakukan studi pustaka lainnya seperti buku, jurnal, artikel, peneliti terdahulu.

\section{HASIL DAN PEMBAHASAN}

Kemajuan sains dan teknologi telah memberikan kemudahan-kemudahan dan kesejahteraan bagi kehidupan manusia sekaligus merupakan sarana bagi kesempurnaan manusia sebagai hamba Allah dan khalifah-Nya karena Allah telah mengaruniakan anugerah kenikmatan kepada manusia yang bersifat saling melengkapi yaitu anugerah agama dan kenikmatan sains teknologi. Penerapan sains dalam dunia modern telah menghasilkan banyak teknologi yang membuat kehidupan manusia lebih baik, lebih nyaman dan aman. Oleh karena itu, sain merupakan sebuah karunia dari Allah SWT (Mundilarto, 2013).

Dalam sains biologi mengandung sistem nilai dan moral yang dapat dipelajari oleh manusia, karena pada dasarnya bahan ajar merupakan ayat-ayat kauniyah atau hukum alam (menurut istilah orang Barat) disamping banyak pula yang terkait dalam ayat-ayat qauliyah (ayat-ayat tersurat dalam kitab suci Al-Qur'an. Tujuan pembelajaran sains adalah mencakup pengembangan ranah kognitif (pengetahuan), afektif (sikap), dan psikomotor (keterampilan) serta ranah interkonektif (perpaduan dari ketiga ranah tersebut) yang melahirkan suatu kreativitas untuk dapat menggali sistem nilai dan moral yang dikandung oleh setiap bahan ajarnya. Albert Einsten (Yudianto, 2016) berpendapat bahwa sains mengandung nilai praktis, pendidikan, intelektual, nilai sosial politik dan religius.

Peran religiusitas sangat berarti dalam mencapai kesejahteraan kehidupan manusia, karena dipandang sebagai faktor penting bagi penataan kehidupan manusia serta segala aktivitas yang merujuk pada penguasan ilmu pengetahuan dan teknologi. Semua kebenaran dan pengetahuan yang diperoleh lewat sains, seluruhnya telah Allah tunjukkan dalam Al-Qur'an bahkan sebelum fakta sains itu ditemukan. Keberadaannya menunjukkan bahwa penyelidikan dan penguasaan manusia tentang sains merupakan bagian dari berkah Allah SWT, sebagmana firman Allah dalam surat Al-Kahfi ayat 109 yang artinya "Katakanlah : Kalau Sekiranya Lautan Menjadi Tinta Untuk (Menuliskan) Kalimat-Kalimat Tuhanku, Sungguh Habislah Lautan Itu Sebelum Habis (Dituliskan) Kalimat-Kalimat Tuhanku, Meskipun Kami Datangkan Tambahan Sebanyak Itu (Pula)."

Ayat tersebut memberikan pesan bahwa sains harus memiliki peran dan fungsi spiritual di samping fungsi intelektualnya dalam membantu memenuhi kebutuhan religius manusia. Sikap religius merupakan sikap dan perilaku yang dekat dengan halhal spiritual. Seseorang disebut religius ketika ia merasa perlu dan berusaha mendekatkan dirinya dengan Tuhan Yang Maha Esa, dan patuh melaksanakan ajaran agama yang dianutnya. Religiusitas merupakan sikap batin seseorang ketika berhadapan realitas kehidupan luar kemampuan dirinya misalnya hidup, mati, kelahiran, bencana banjir, tanah longsor, gempa bumi, dan sebagainya. Sebagai orang yang bertuhan kekuatan itu diyakini sebagai kekuatan Tuhan.Menyadari tentang kekuatan tersebut seharusnya memberikan dampak positif terhadap perkembangan hidup seseorang apabila ia menemukan maknanya. Manusia akan mampu menemukannya apabila ia berani merenung dan merefleksikannya. Melalui refleksi pengalaman hidup inilah, seseorang dapat menyadari, memahami, dan menerima keterbatasan dirinya sehingga terbangun rasa syukur kepada Tuhan Yang Maha Esa.

Untuk menumbuhkan nilai-nilai religius, memerlukan strategi guru sebagai pendidik dalam pelaksanaannya. Nilainilai religius dapat diajarkan kepada peserta didik di sekolah melalui kegiatan belajar 
yang terintegrasi dengan mengaitkan nilainilai agama dengan sains. Dalam Al-Quran sendiri tidak mempertentangkan antara sains dan agama. Bahkan dalam banyak ayat-Nya ditekankan agar manusia senantiasa memikirkan kejadian di alam untuk memperteguh keyakinan agamanya (QS. 21 :30) (Ali, 1996 ). Sains dalam hal ini juga bukan merupakan bagian yang terpisah dari agama. Sains merupakan bagian yang integral dari agama Islam (Bakar, 1994; Shihab, 2000; Yaqub, 1980).

Al-Quran menyatakan bahwa sains, seperti halnya sains tentang kehidupan manusia merupakan bagian integral dari agama. Sains mengajarkan kepada manusia tentang bagaimana mengelola alam semesta agar bermanfaat untuk manusia, melakukan berbagai proses, serta memproduksi sesuatu untuk kebutuhan hidup. Sementara itu agama mengajarkan manusia tentang sistem nilai (Ali, 1996 ). Agama mengajarkan tentang nilai ketakwaan terhadap Khaliq serta nilai kebaikan terhadap sesama (Al Ghazali, 1995 ; Almath, 1993). Hal yang harus mendapatkan perhatian yaitu pernyataan bahwa Kitab Suci Al-Quran berasal dari Allah yang memiliki kebenaran mutlak. Kebenaran yang mutlak ini menyebabkan Al-Quran dapat dijadikan sebagai alat untuk menguji kebenaran prinsip-prinsip sains. Apabila penemuan sains bertentangan dengan Al-Quran maka hal itu disebabkan karena masih sangatnya terbatasnya metode investigasi yang dapat dikembangkan oleh manusia (Ali, 1996 ). Dukungan terhadap pernyataan ini dikemukakan oleh Lawson (1995), yang menyatakan bahwa terdapat dua perbedaan pendekatan yang esensial antara sains dan agama. Agama mempercayai sesuatu berdasarkan keyakinan, sementara sains mempercayai sesuatu berdasarkan evaluasi fakta dan penalaran.

Meskipun demikian, kebenaran dalam agama adalah kekal sementara kebenaran dalam sains hanya bersifat tentatif (sementara). Tidak dapat dikatakan Islami apabila pola pendidikan sains dan teknologi sangat kurang porsinya, karena telah dinyatakan dalam Al-Quran bahwa berbagai fakta penciptaan di alam hanya dapat dipahami dengan pengetahuan dan teknologi. Seandainya seorang muslim berpegang teguh pada Al-Quran dan hadist, maka mempelajari sains dengan baik merupakan hal yang wajib. Dengan demikian, dalam mempelajari nilai-nilai kehidupan melalui sains, aspek penguasaan konsep sains dan teknologi tetap harus mendapat penekanan. Tidak ada pendidikan yang disebut Islami apabila pendidikan tersebut tidak menempatkan sains sebagai komponen sangat penting (Ali, 1996).

Nilai religius suatu bahan ajar dalam IPA adalah kandungan nilai yang dapat meningkatkan keyakinan terhadap Allah. Keteraturan, keseimbangan, peristiwa sebab akibat, dan lain sebagainya merupakan aspek yang dapat menumbuhkan kesadaran bahwa segala hal yang terjadi mesti ada yang menciptakan dan mengaturnya (Yudianto, 2001). Menurut Yahya (Sauri, 2002) Sains atau IPA merupakan cara tepat untuk mengenal Allah. Pengamatan ilmiah terhadap aspek-aspek kehidupan dapat memperkenalkan manusia terhadap misteri penciptaan, dan akhirnya mengarah pada pengenalan pengetahuan, kebijakan, dan kekuasaan tanpa batas yang dimiliki Allah. Contoh nilai religius yang dapat dikembangkan dari pembelajaran konsep biologi yaitu sistem peredaran darah pada manusia menurut Depriya \& Ratnawulan (2002) antara lain: Arsitektur struktur arteri dan vena disesuaikan dengan fungsinya. Arteri berdinding tebal karena harus memompa darah dari jantung ke seluruh tubuh. Dengan demikian, agar dinding arteri tidak jebol (pecah) karena tekanan yang tinggi maka dindingnya harus tebal dan kuat. Vena berdinding tipis dan mempunyai katup berfungsi mengalirkan darah menuju ke jantung. Pembuluh ini berdinding tipis karena hanya memerlukan tekanan untuk membawa darah ke jantung. Pembuluh vena dilengkapi dengan katup untuk menjaga agar darah tidak mengalir mundur. Struktur kedua pembuluh darah yang sempurna sesuai dengan fungsinya ini 
menunjukkan tanda-tanda kebesaran Allah serta Maha kayaNya ilmu Allah dalam mengatur suatu kesatuan organ yang berfungsi dengan baik.

Berkenaan dengan hal tersebut, Allah swt., berfirman dalam Q.S. Al-Hijr : 21 dan Q.S. Al-Infithaar : 7 sebagaimana berikut:

1. Dan tidak ada sesuatupun melainkan pada sisi khazanah-Nya, dan Kami tidak menurunkannya melainkan dengan ukuran tertentu.(Q.S. Al-Hijr : 21)

2. Yang telah menciptakan kamu lalu menyempurnakan kejadian kamu dan menjadikan (susunan) tubuhmu seimbang . (Q.S. Al-Infithaar : 7)

Menurut Rustaman (1997) tujuan pembelajaran sains (IPA) selain untuk memahami konsep-konsep sains dan keterkaitannya, juga ditujukan untuk Meningkatkan keimanan akan kebesaran serta kekuasaan Tuhan Yang Maha Esa, sehingga menurut Yunus dan Pasha (Sauri, 2016) mengungkapkan bahwa nilai-nilai Imtaq dapat diajarkan kepada siswa antara lain melalui pembelajaran biologi dengan mencontohkan materi ajar alat indera. Melalui pembelajaran ini siswa dapat diberikan pemahaman bahwa alat indera merupakan anugerah dari Allah SWT agar manusia bersyukur dengan cara menggunakannnya untuk mencari kebenaran dan keyakinan terhadap ayat/ayat Allah, baik ayat kauliyah maupun ayat kauniyah. Selain dari itu siswa diajak untuk menggunakan alat indera dalam rangka mencari keridhoan Allah, tidak menggunakannya untuk keburukan, karena semuanya akan dimintai pertanggung jawaban oleh Allah swt. Menemukan kebenaran sains dengan agama akan menumbuhkan prinsip dan keyakinan beragama sehingga siswa tidak mudah goyah manakala dihadapkan pada berbagai idiologi atau paham yang berkembang.

Keyakinan beragama pada saat ini mesti dimiliki oleh setiap manusia dalam kehidupannya, karena setiap saat manusia akan dihadapkan kepada berbagai pilihan, mana yang dilakukan dan mana yang tidak dilakukan. Manusia mengambil keputusan ini yang dilakukan, dan ini yang mesti ditinggalkan. Setiap keputusan memiliki konsekuensinya masing-masing memilih suatu tindakan akan membuka konsekuensi, dan memilih tidak berbuat sesuatu pun akan menimbulkan konsekuensi bagi si pengambil keputusan. Ketika manusia mengambil keputusan, tentunya ada seperangkat atau sejumlah nilai yang melandasi pilihan manusia. Juga ada seperangkat nilai yang menjadi rujukan dan pertimbangan pilihan manusia. Menurut Sanusi (2015) nilai menjadi driving force yang mendorong manusia bertindak. Jadi, nilai-nilai tersebut bukan hanya menjadi landasan dan rujukan cara bertindak dan saat melakukan tindakan, melainkan juga mewarnai sebuah tindakan, karena nilai merupakan keyakinan yang menjadi dasar pemikiran seseorang sehingga memberikan motivasi bagi seseorang untuk bertindak dan berperilaku, karena suatu nilai akan dipandang baik, akan dipandang benar dan sah untuk dilakukannya. Nilai dalam diri seseorang menurut Hakam (2016) akan diwujudkan dalam perkataan dan perbuatannya, perkataan dan perbuatan seseorang mencerminkan nilai dirinya. Apa yang dikatakan seseorang dan apa yang dilakukan seseorang mencerminkan derajat kebernilaian seseorang.

Ketika nilai berada dalam pikiran seseorang, maka nilai itu menjadi konsep penting dalam hidup, sehingga konsep atau gagasan itu dijadikan standar perilakunya, yaitu standar untuk menampilkan keindahan, keefisienan, atau kebermaknaan yang ia dukung dan dipertahankannya, meskipun tidak selalu disadari. Setelah seseorang bersentuhan dan mengetahui sesuatu nilai, nilai tersebut lambat laun akan mempengaruhi keyakinannya, sehingga nilai menjadi dasar pemikiran bahkan menjadi dasar tindakannya. Karena itu, nilai memberikan dorongan kepada individu untuk memilih dan berbuat, dan memberikan dorongan kepada individu untuk memilih dan menolaknya sehingga ia menghindari sesuatu. Akhirnya, nilai yang ada dalam diri seseorang mempengaruhi orang tersebut untuk menentukan apakah 
sesuatu itu sah atau tidak sah, apakah sesuatu itu baik atau buruk, bahkan apakah sesuatu itu benar atau salah.

Nilai tidak hadir pada dunia pengalaman, tetapi hadir dalam dunia pikiran manusia. Nilai adalah standar kelakuan, keindahan, efisiensi, atau kebermaknaan yang seseorang dukung dan yang mereka coba untuk nikmati atau pertahankan. Sebagai standar nilai menolong kita untuk menetapkan sesuatu yang kita sukai atau tidak. Dalam cara yang lebih luas, nilai menolong kita untuk

\section{KESIMPULAN}

Ketika nilai berada dalam pikiran seseorang, maka nilai itu menjadi konsep penting dalam hidup, sehingga konsep atau gagasan itu dijadikan standar perilakunya, yaitu standar untuk menampilkan keindahan, keefisienan, atau kebermaknaan yang ia dukung dan dipertahankannya, meskipun tidak selalu disadari. Setelah seseorang bersentuhan dan mengetahui sesuatu nilai, nilai tersebut lambat laun akan mempengaruhi keyakinannya, sehingga nilai menjadi dasar pemikiran bahkan menjadi dasar tindakannya.

Nilai religius suatu bahan ajar dalam IPA adalah kandungan nilai yang dapat meningkatkan keyakinan terhadap Allah. Keteraturan, keseimbangan, peristiwa sebab akibat, dan lain sebagainya merupakan aspek yang dapat menumbuhkan kesadaran bahwa segala hal yang terjadi mesti ada yang menciptakan dan mengaturnya, sehingga tujuan pembelajaran sains (IPA) selain untuk memahami konsep-konsep sains dan keterkaitannya, juga ditujukan untuk meningkatkan keimanan akan kebesaran serta kekuasaan Tuhan Yang Maha Esa.

\section{DAFTAR PUSTAKA}

Ali, Mukti (1991). Memahami Beberapa Aspek Ajaran Islam,Yogyakarta: Mizan menentukan apakah sesuatu yang khusus (suatu objek, seseorang, suatu gagasan, cara berperilaku dll) atau kelas tertentu itu baik atau buruk.

Dengan demikian standar yang lebih penting kita miliki adalah standar untuk mempertimbangkan kelakuan kita, yang dengan pertimbangan itu kita tentukan jenis-jenis perbuatan mana yang tidak pantas atau tidak bernilai. Standar tersebut adalah nilai moral kita. Nilai moral menggambarkan petunjuk terhadap apa yang benar dan adil.

Ansori, Yoyo Zakaria .(2017). Education Leadership Values in Students' Character Building: Conference: The 2nd International Conference on Sociology Education: Bandung

.(2019). Mewujudkan Kultur Sekolah Berkarakter Melalui Kepemimpinan Berbasis Nilai. Elementaria Edukasia: Universitas Majalengka

Bakar,Osman. (1994).Tauhid dan Sains, terj.Yuliani Liputo. Jakarta: Pustaka Hidayah.

,Osman.(2006).Classification of Knowledge in Islam. KualaLumpur: International of Islamic Thoughtand Civilization, International Islamic University Malaysia.

Daniah (2014) Model Pembinaan Karakter Religius Terintegrasi Pada Pembelajaran Sains Di Pendidikan Dasar (Studi Deskriptif di Beberapa Sekolah Dasar di Kecamatan Pegaseng Aceh Tengah) UIN ArRaniry: Banda Aceh

El-Bassiouny, Noha .(2008). The Importance of Character Education for Tweens as Consumers. German University in Cairo: Egypt 
Depriya, M. \& Wulan, A.R. 2002. Pendidikan Nilai pada pembelajaran biologi. Buletin PWKG Diknas.

Ghazali-Al (1995). Ihya' 'Ulumuddin. Beirut, Libanon: Daarul Fikr

Hakam, K.A .(2013). Pendekatan Pendidikan Karakter di Sekolah Dasar. UPI: Bandung

Hamzah Ya'qub .(1988). Etika Islam Pembinaan Akhlakul Karimah (Suatu Pengantar), Bandung, CV. Diponegoro, 1988

Lawson, A.E. (1995). Science teaching and The Development of Thinking, California, Wadsworth Publishing Company Belmont.

Lickona, T. (1991). Educating for Character, How Our Schools can Teach Respect and Responsibility, New York, Bantam Books.

M., Ali dan Luluk Y. R., (2004). Paradigma Pendidikan Universal di Era Modern dan Post-Modern; Mencarai "Visi Baru" atas "Realitas Baru” Pendidikan Kita.Yogyakarta: Institute for Religion and Civil Society Development (Ircisod).

Mundilarto .(2013).Membangun Karakter Melalui Pembelajaran Sains. FMIPA Universitas Negeri Yogyakarta.

Nurihsan, A.J .(2016). Membangun Peradaban Melalui Pendidikan dan Bimbingan. Refika Aditama: Bandung.
Ratna, Nyoman Kutha .(2010). Metodologi Penelitian: Kajian Budaya dan Ilmu Sosial Humaniora Pada Umumnya. Yogyakarta: Pustaka Pelajar.

Rustaman, Nuryani Y., dkk. 2003. Strategi Belajar Mengajar Biologi. Bandung: UPI.

Sanusi, A. (2014). Sistem Nilai, Nuansa Cendekia, Bandung.

Sauri, Sofyan .(2009). Kepemimpinan Berbasis Nilai: Membangun Kembali Komitmen, Kinerja dan Produktivitas Karyawan. Bandung: UPI.

Shihab, M. Quraish. (2000). Tafsir alMisbah, Vol: 1, cet-10, Ciputat: Lentera Hati.

Stronger, James .(2013). Qualities of effective Principals, ASCD: USA.

Sugiyono. (2016). Metode Penelitian Kuantitatif Kualitataif dan Kombinasi (Mixed Methods).Bandung: Alfabeta.

Yudianto, Suroso Adi .(2016). Manajemen Alam: Sumber Pendidikan Nilai: Mughni Sejahtera: Bandung.

(2001). Buku Materi Pokok Biologi Umum Bernuansa IMTAK. Bandung: BEP Kanwil DEPAG-IAIN Sunan Gunung Djati. 